\title{
Harvest frequency and burning effects on mono- cultures of 3 warm-season grasses
}

\author{
GREGORY J. CUOMO, BRUCE E. ANDERSON, LINDA J. YOUNG, AND WALLACE W. \\ WILHELM
}

\begin{abstract}
Authors are assistant professor, Louisiana State University Agricultural Center, Franklinton La., 70438, professor, Agronomy Dep., associate professor, Biometry Department, and plant physiologist, USDA-ARS, Agronomy Dep., University of Nebraska-Lincoln, 68583-0910. At the time of research, the senior author was research technologist, Agronomy Dep., University of Nebraska-Lincoln, Lincoln, Nebr.
\end{abstract}

\begin{abstract}
Harvest frequency and burning can affect forage yield of monocultures of switchgrass (Panicum virgatum $\mathbf{L}$.), big bluestem (Andropogon gerardii Vitman), and indiangrass [Sorghastrum nutans (L.) Nash]. Current information is based largely on results from mixed stands. A field experiment was established in 1986, and from 1988 to 1991 treatments were applied with burning in March, April, or May plus an unburned control. Growingseason yield was measured by harvesting 1 (June), 2 (June and July), or 3 (June, July, and August) times with unharvested control plots included. End-of-season standing crop from all plots was determined after plants became dormant. Treatments were applied to the same plots annually and were arranged in a splitsplit plot, randomized complete block design. The main plot was species, subplot was burn date, and sub-subplot was harvest frequency. Burning reduced yields $(P<0.01)$, and yields were lowest in plots burned in May. Burning reduced yields of indiangrass most (57\%) and big bluestem least (15\%). In 1989, plots harvested three times produced yields similar to plots harvested once for all species. By 1991, yields of plots harvested 3 times per growing-season were reduced $(\mathrm{P}=0.08)$ below those of plots harvested once. Yield response of species also varied across the study. Growing-season yields in 1991 were 113, 67, and 89\% of 1989 yields for switchgrass, big bluestem, and indiangrass, respectively. Regardless of burning and harvest frequency combination, switchgrass produced as much or more herbage than the other species.
\end{abstract}

Key Words: Soil moisture, yield, Andropogon gerardii, Panicum virgatum, Sorghastrum nutans.

Switchgrass (Panicum virgatum L.), big bluestem (Andropogon gerardii Vitman), and indiangrass [Sorghastrum nutans (L.) Nash] are dominant warm-season grasses that are important forage resources in the tallgrass prairie region of the central United States. Grazing or haying, and fire, are commonly applied management practices that may affect the productivity of these species.

Journal Series No. 10587, Agricultural Research Division, University of Nebraska.

Manuscript accepted 22 April 1995.
Weaver and Hougen (1939) reported that big bluestem clipped 6 times per year during the growing-season for 2 years yielded $40 \%$ less herbage than plants clipped only once following dormancy. Similarly, Anderson and Matches (1983) found that harvesting switchgrass 3 times per year reduced yields 34 to $60 \%$ during the second year. Ehrenreich and Aikmann (1957) concluded that decreased yields with frequent defoliation were a result of reduced photosynthetic surface area.

Previous research on the effects of fire on herbaceous production in the tallgrass prairie has provided contradictory results. Some researchers found fire increased productivity in the tallgrass prairie (Ehrenreich and Aikmann 1957, Rice and Parenti 1978, Knapp 1985, Svejcar and Browning 1988, Mitchell 1992), while others found fire reduced or did not affect productivity (McMurphy and Anderson 1963, Owensby and Anderson 1967, Anderson et al. 1970). Increases in productivity were generally found in high precipitation zones when burning occurred after several years of little or no forage removal (Ehrenreich and Aikmann 1957, Rice and Parenti 1978, Knapp 1985). On such sites with accumulated dead biomass, burning may improve the environment for growth of warm-season grasses by providing warmer soil temperatures, increased light penetration to emerging shoots, and reduced allelopathic effects associated with decay of dead plants (Hulbert 1984). Burning may not improve the growth environment if rainfall is below average, or in zones with less precipitation.

Declines in productivity with burning may also be associated with burn date. Anderson (1965) determined that productivity was less with 20 March and 10 April burns than 1 May burn.

Some fire and harvest management effects on the yield of these species may be explained by soil water content, since soil water availability often limits growth in grasslands (Anderson et al. 1970, Ogden and Loomis 1972). Further, burning has been shown to reduce soil water content (Ehrenreich and Aikmann 1957, Anderson 1965, Anderson et al. 1970).

Most research on warm-season grasses has focused on mixed stands, thus interactions among species may mask the effect of burning and harvest frequency on individual species and may account for some of the different results. This study was conducted in pure stands in order to more precisely measure the effect of burn date and harvest frequency on forage yield of switchgrass, big bluestem, and indiangrass grown in monocultures. 


\section{Materials and Methods}

The study was conducted at the University of Nebraska, Agricultural Research and Development Center near Mead, Nebraska ( $96^{\circ} 33^{\prime} \mathrm{W}$. long., $41^{\circ} 1 \mathrm{l}^{\prime} \mathrm{N}$. lat., $315 \mathrm{~m}$ elev.), which is located near the western edge of what was once the tallgrass prairie. The soil is a Sharpsburg silty clay loam (fine montmorillonitic mesic Typic Argiudoll) derived from loess materials, with the A horizon extending to a depth of approximately $35 \mathrm{~cm}$. The capability classification is IIe.

The climate is continental. Long term average precipitation at the research site is $68 \mathrm{~cm}$ with $50 \mathrm{~cm}$ occurring between 1 April and 30 September. Both 1988 (44.6 $\left.\mathrm{cm} \mathrm{yr}^{-1}\right)$ and $1989\left(50.2 \mathrm{~cm} \mathrm{yr}^{-1}\right)$ were relatively dry years; precipitation was near normal in $1990(68.7 \mathrm{~cm}$ $\left.\mathrm{yr}^{-1}\right)$; and it was above normal in $1991\left(81.4 \mathrm{~cm} \mathrm{yr}^{-1}\right)$. Growing-season precipitation (March-September) followed a similar pattern (37.8, 42.3, 58.6, and $68.1 \mathrm{~cm} \mathrm{yr}^{-1}$ for $1988,1989,1990$, and 1991, respectively).

In 1986, monocultures of 'Pawnee' big bluestem, 'Nebraska 54 ' indiangrass, and 'Trailblazer' switchgrass were planted in $5 \mathrm{x}$ 44-m plots. Three replicates of each species were arranged in a randomized complete block design. The area containing all treatment plots was mowed and herbage removed in August 1987. A mixture of $1.1 \mathrm{~kg}$ a.i. ha ${ }^{-1}$ of atrazine [6-chloro-N-ethyl-N'-Clmethylethyl-1,3,5-triazine-2,4-diamine] and $1.1 \mathrm{~kg}$ a.i. $\mathrm{ha}^{-1}$ of alachlor [2-chloro-2' 6 '-diethyl-N-(methoxymethyl)acetanilide] was applied in water in a dilution volume of 260 liters $\mathrm{ha}^{-1}$ during late April 1990 and 1991 to maintain stand purity. Herbicides were used because weed infestations may have been different for species and treatments and therefore may have masked treatment effects.

Each main plot strip was divided into four, $5 \times 9$-m subplots with $1.5-\mathrm{m}$ borders separating the subplots. Three burn treatments were applied on randomly selected subplots in mid-March when plants were still dormant, in mid-April, with approximately 1 to 5 $\mathrm{cm}$ of new growth, or in mid-May with approximately 15 to 20 $\mathrm{cm}$ of new growth. An unburned subplot was used as a control. The same burn treatments were reapplied to the same subplots each year.

Each burn subplot was further divided into four, $1.5 \times 5 \mathrm{~m}$ subsubplots. Sub-subplots were harvested 1 (July), 2 (June and July), or 3 (June, July, and August) times, or not harvested during each growing-season. Herbage was harvested and removed from a $1 \times$ $5 \mathrm{~m}$ area in each sub-subplot with each growing-season harvest using a flail type forage harvester. The remaining vegetation was mowed with a sickle-bar mower and left on the plot for litter accumulation and fuel for burning. Plots were harvested to leave a stubble height of $18 \mathrm{~cm}$. The same growing-season harvest treatments were applied to the same sub-subplots each year.

In October, after killing freezes caused above ground growth to cease, an end-of-season harvest was taken by hand clipping a 30 $\times 180 \mathrm{~cm}$ area to a height of $18 \mathrm{~cm}$ from non-harvested sub-subplots in 1989, and from all sub-subplots in 1990. At the conclusion of the study in 1991, all plots were harvested with the forage harvester following onset of dormancy in October. No end-ofseason clipping was taken from harvested plots in 1989. Yield from the October harvest was added to the yield from growingseason harvests to calculate total annual yield. Since no end-ofseason clip was taken from harvested plots in 1989 , no total annual yield could be calculated.
At each harvest, fresh cut herbage was weighed and a $150 \mathrm{~g}$ subsample collected, dried in a forced air oven at $60^{\circ} \mathrm{C}$ for 2 days and weighed to determine percent dry matter, which was used to calculate herbage dry matter yield.

Soil water content was measured by installing an aluminum access tube to a $1.7 \mathrm{~m}$ depth in each non-harvested and twice-harvested sub-subplot of each species. Soil moisture measurement in other harvest treatments was omitted. Soil water content was measured with a neutron scattering device at $30-\mathrm{cm}$ intervals from 30 to $150 \mathrm{~cm}$ below the soil surface. Soil water content was measured periodically from mid-August until November in 1989. In 1990 and 1991, soil water content was periodically measured from March to November.

The study was designed as a split-split plot in time and analyzed using both repeated measures analysis and GLM procedures (SAS 1988). A univariate rather than a multivariate approach to repeated measures analysis was used because treatment-difference variances were determined to be homogeneous (Maxwell and Delaney 1990). This is similar to assuming the population covariance matrix has a certain form, "sphericity" or "circularity" (Huynh and Feldt 1970). Even the most stringent test for sphericity, the Greenhouse-Geisser test, (Greenhouse and Geisser 1959), indicated no violations of assumptions for variances, so univariate analysis of repeated measures was deemed appropriate. Univariate repeated measures analysis gives little control of the over-year error terms necessary to calculate the correct F-tests for the split-split plot design. Because the outcome of F-tests was similar between the repeated measures and the split-split plot in time analyses, and because the split-split plot in time gives greater control of error terms, $\mathrm{F}$ values and probabilities from the split-split plot in time are used for data presented in the text.

\section{Results and Discussion}

\section{Growing-season Yield}

Year by species by burn interactions were significant $(\mathrm{P}=0.01)$ for growing-season yield (Table 1). In 1989, unburned plots produced more $(P=0.01)$ growing-season yield than burned plots, and plots burned in March or April produced more growing-sea-

Table 1. Growing-season yield of switchgrass, big bluestem, and indiangrass at 4 burn dates averaged across 3 growing-season harvest frequencies in 1989-1991 (year by species by burn date interaction $\mathrm{P}<\mathrm{F}=0.01 ; \mathrm{LSD}_{0.05}=300 \mathrm{~kg} \mathrm{ha}^{-1}$ ).

\begin{tabular}{|c|c|c|c|c|}
\hline \multirow[b]{2}{*}{ Species } & \multirow[b]{2}{*}{ Bum date } & \multicolumn{3}{|c|}{ Year } \\
\hline & & 1989 & 1990 & 1991 \\
\hline & & \multicolumn{3}{|c|}{$\ldots \ldots\left(\mathrm{kg} \mathrm{ha}^{-1}\right) \ldots \ldots$} \\
\hline Switchgrass & $\begin{array}{c}\text { Not burned } \\
\text { March } \\
\text { April } \\
\text { May }\end{array}$ & $\begin{array}{l}3360 \\
2070 \\
1980 \\
1580\end{array}$ & $\begin{array}{l}3440 \\
2770 \\
2310 \\
1730\end{array}$ & $\begin{array}{l}3840 \\
2520 \\
2510 \\
1330\end{array}$ \\
\hline Big bluestem & $\begin{array}{c}\text { Not burned } \\
\text { March } \\
\text { April } \\
\text { May }\end{array}$ & $\begin{array}{l}3660 \\
2350 \\
2060 \\
1650\end{array}$ & $\begin{array}{l}2710 \\
2630 \\
2200 \\
1700\end{array}$ & $\begin{array}{l}1850 \\
1870 \\
1610 \\
1250\end{array}$ \\
\hline Indiangrass & $\begin{array}{l}\text { Not burned } \\
\text { March } \\
\text { April } \\
\text { May }\end{array}$ & $\begin{array}{r}3310 \\
1140 \\
1250 \\
670\end{array}$ & $\begin{array}{r}2750 \\
1780 \\
1670 \\
920\end{array}$ & $\begin{array}{r}2490 \\
1170 \\
1270 \\
760\end{array}$ \\
\hline
\end{tabular}


son yield than May burned plots for each species. This difference held true in subsequent years for switchgrass and indiangrass except in 1990 when switchgrass burned in March produced more growing-season yield than switchgrass burned in April. Not burned big bluestem growing-season yield declined relative to burned big bluestem yields from 1989 to 1991 . Averaged across burn treatments in 1991, burning reduced indiangrass growingseason yields more $(57 \% ; \mathrm{P}=0.09)$ than big bluestem $(15 \%)$ or switchgrass $(50 \%)$.

Growing-season yields in 1991 were 113,67, and 89\% of 1989 yiclds for switchgrass, big bluestem and indiangrass, respectively (averaged across burn and harvest frequency treatments). The reduction in big bluestem yield indicates that although big bluestem dominates much of the tallgrass prairie region of the Great Plains, environmental conditions do not always favor its expansion when planted in monocultures.

The lower yield of burned plants in this study contradicts results of some researchers (Ehrenreich and Aikmann 1957, Rice and Parenti 1978, Knapp 1985, Svejcar and Browning 1988). Fire may not increase yield on sites without accumulated biomass. Anderson et al. (1970) found no increase in yield on annually burned Flint Hills tallgrass prairie, and Ehrenreich and Aikmann (1957) found no increase in yield with a second consecutive year of burning in Iowa prairies. Ehrenreich and Aikmann (1957) concluded that in Iowa prairies, 4 to 6 years without burning was needed to develop sufficient mulch to suppress warm-season grass growth. In this study, the relatively young stands in nonburned plots may not have accumulated enough mulch to inhibit growth.

Year by species by harvest frequency interactions were also significant for growing-season yield ( $P=0.08$; Table 2$)$.

Table 2. Growing-season yield of switchgrass, big bluestem, and indiangrass for 3 growing-season harvest frequencies averaged across 4 burn dates in 1989-1991 (year by species by harvest frequency interaction $\left.\mathrm{P}<\mathrm{F}=0.08 ; \mathrm{LSD}_{0.05}=450 \mathrm{~kg} \mathrm{ha}^{-1}\right)$.

\begin{tabular}{lcccc}
\hline \hline \multirow{2}{*}{ Species } & Harvest frequency & \multicolumn{3}{c}{ Year } \\
\cline { 3 - 5 } Switchgrass & 1 & 1989 & 1990 & 1991 \\
\hline \multirow{4}{*}{ Big bluestem } & 2 & 2310 & 3040 & 3060 \\
& 3 & 2210 & 2250 & 2320 \\
& 1 & 2220 & 2410 & 2270 \\
Indiangrass & 2 & 2690 & 2440 & 2070 \\
& 3 & 2050 & 2190 & 1560 \\
& 2 & 2540 & 2310 & 1300 \\
& 3 & 1540 & 1990 & 1770 \\
& 1 & 1370 & 1740 & 1300 \\
& 3 & 1860 & 1600 & 1200 \\
\hline
\end{tabular}

Harvest frequency:

$\mathrm{I}=$ June harvest

$2=$ June and July harvests

$3=$ June, July, and August harvests

Switchgrass yield increased or was unchanged for all harvest frequencies from 1989 to 1991 . In addition, switchgrass was more tolerant of 3 harvests during a growing-season than the other species. Big bluestem yields declined for all harvest frequencies from 1990 to 1991 . Yields of indiangrass harvested 1 or 2 times during the growing-season were similar in 1989 and 1991 but, yield of indiangrass harvested 3 times per growing-season declined as the study progressed.
In 1989, indiangrass and big bluestem harvested 3 times per growing-season produced similar yields to plots harvested 1 time (Table 2). By 1991, plots harvested 3 times during the growingseason yielded less than plots harvested once. These results concur with those of Weaver and Hougan (1939), Ehrenreich and Aikmann (1957), and Anderson and Matches (1983) who found frequent harvests decreased productivity of warm-season grasses over time.

The more erect growth form and earlier emergence of switchgrass reproductive tillers (Moser and Vogel 1995) would lead one to believe that multiple harvests would be more detrimental to switchgrass than to the other species. But, these data show the opposite to be true. Tiller density of switchgrass was less than that of big bluestem or indiangrass (Cuomo 1992). In addition, basal cover tended to be less for switchgrass than for the other species (Cuomo 1992). This may have resulted in less interspecific competition and more vigorous plants in switchgrass monocultures.

Interactions between burn date and harvest frequency were also significant $(\mathrm{P}=0.01)$ for growing-season yield. Plots that were not burned, or burned in March (before growth started in the spring) had lower growing-season yields with increasing harvest frequency (Fig. 1). Yield was not reduced as much by multiple harvests on plots burned after plants began growth in spring (April and May burns). This response was consistent over years (year by burn by harvest frequency interaction $\mathrm{P}=0.35$ ) and not different among species (species by burn by harvest frequency interaction $\mathrm{P}=0.61$ ). Plants harvested once or twice each growing-season were growing more vigorously early in spring than plants harvested three times per growing-season (Cuomo 1992) and appeared to be injured more by later burns. For example, plots harvested twice each growing-season yielded $78,46,16$, and $5 \%$ more $(\mathrm{P}=0.01)$ at the June harvest than those harvested 3 times for non-burned, March, April, and May burned plots, respectively (averaged over species and burn treatments).

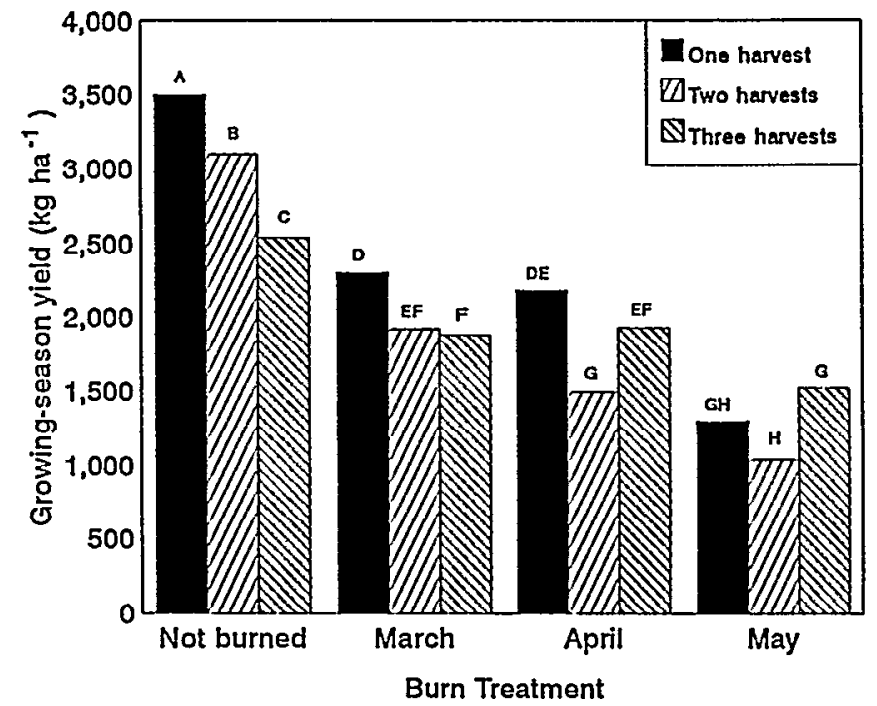

Fig. 1. Growing-season yield of 3 warm-season grass species for 4 burn treatments and 3 harvest frequencies near Mead, Neb. (burn date by harvest frequency interaction $P<F$ 0.01; LSD0.05 $=270$ ). Values represent averages from 1989-1991. Burn by harvest frequency bars with the same letter above them are not significantly different. 


\section{Total Annual Yield}

An end-of-season harvest was taken after frost in 1990 and 1991. Total annual yield was growing-season yield plus the endof-season harvest. Species by burn by harvest frequency interactions were significant $(\mathrm{P}=0.03)$ for total-annual yield (Table 3$)$. Not burned switchgrass produced more total annual yield than the other species, while big bluestem was least affected by burning. Total annual yield of big bluestem that was not burned or harvested during the growing-season was $62 \%$ of switchgrass (Table 3 ). Big bluestem produced $116 \%$ as much total annual yield as switchgrass when averaged across the burned plots that were not harvested during the growing season.

Table 3. Total annual dry matter yield ${ }^{1}$ of switchgrass, big bluestem, and indiangrass at 4 burn dates and 4 harvest frequencies. Values represent averages across 1990 and 1991 (species by burn date by harvest frequency interaction $\mathrm{P}<\mathrm{F}=0.03 ; \mathrm{LSD}_{0.05}=890 \mathrm{~kg} \mathrm{ha}^{-1}$ ).

\begin{tabular}{|c|c|c|c|c|}
\hline Bum date & $\begin{array}{c}\text { Harvest } \\
\text { frequency }^{2}\end{array}$ & $\begin{array}{l}\text { Switch- } \\
\text { grass }\end{array}$ & $\begin{array}{c}\text { Big } \\
\text { bluestem }\end{array}$ & $\begin{array}{c}\text { Indian- } \\
\text { grass }\end{array}$ \\
\hline & & \multicolumn{3}{|c|}{$\ldots \ldots \ldots\left(\mathrm{kg} \mathrm{ha}^{-1}\right) \ldots \ldots \ldots$} \\
\hline Not bumed & $\begin{array}{l}0 \\
1 \\
2 \\
3\end{array}$ & $\begin{array}{l}9580 \\
5790 \\
5100 \\
3310\end{array}$ & $\begin{array}{l}5980 \\
3730 \\
3170 \\
2190\end{array}$ & $\begin{array}{l}5910 \\
4090 \\
3250 \\
2450\end{array}$ \\
\hline March & $\begin{array}{l}0 \\
1 \\
2 \\
3\end{array}$ & $\begin{array}{l}4710 \\
3970 \\
4420 \\
2600\end{array}$ & $\begin{array}{l}5500 \\
3530 \\
2970 \\
2170\end{array}$ & $\begin{array}{l}3610 \\
2100 \\
1820 \\
1310\end{array}$ \\
\hline April & $\begin{array}{l}0 \\
1 \\
2 \\
3\end{array}$ & $\begin{array}{l}5420 \\
4210 \\
3110 \\
2520\end{array}$ & $\begin{array}{l}5680 \\
2850 \\
2410 \\
2380\end{array}$ & $\begin{array}{l}3460 \\
2240 \\
1700 \\
1500\end{array}$ \\
\hline May & $\begin{array}{l}0 \\
1 \\
2 \\
3\end{array}$ & $\begin{array}{l}3300 \\
2350 \\
2200 \\
2510\end{array}$ & $\begin{array}{l}4350 \\
2930 \\
2190 \\
1470\end{array}$ & $\begin{array}{l}2170 \\
1450 \\
1260 \\
1070\end{array}$ \\
\hline
\end{tabular}

Includes yield from growing-season harvest and end-of-season harvest.

${ }^{2}$ Harvest frequency:

$0=$ No harvest during the growing-season

$1=$ June harvest

2 = June and July harvests

A significant year by burn date by harvest frequency interaction $(\mathrm{P}<0.01)$ resulted from the response of these species to the more favorable moisture conditions in 1991 (Table 4). Regardless of the burning date, burning reduced forage yields in this study. This was true even in plots that were not harvested. Compared to 1990 , yield in 1991 was $110,33,38$, and $30 \%$ higher in non-harvested plots that were not burned or non-harvested plots that were burned in March, April, or May, respectively. In addition, compared to 1990 , total annual yield increased $56 \%$ in 1991 on nonharvested plots, increased slightly on plots harvested once (4\%), and declined on plots harvested 2 and 3 times ( 9 and 19\%, respectively). Thus, judicious harvest and burning management may be necessary to maintain productivity in these species when grown in monocultures.

\section{Spring Growth}

At the June harvest for all species, non-burned plots yielded more $(\mathrm{P}<0.01)$ than burned plots and March and April burned plots yielded more than May burned plots. Decreased June yields in later burned plots may have been, in part, the result of early growth being destroyed by burning. Burning in April destroyed
Table 4 . Total annual yield ${ }^{1}$ for 4 burn uates and 4 harvest frequencies in 1990 and 1991, averaged over species (year by burn date by harvest frequency interaction $\mathrm{P}<\mathrm{F}=0.01 ; \mathrm{LSD}_{0.05}=590$ ).

\begin{tabular}{|c|c|c|c|}
\hline \multirow[b]{2}{*}{ Burn date } & \multirow[b]{2}{*}{ Harvest frequency ${ }^{2}$} & \multicolumn{2}{|c|}{ Year } \\
\hline & & 1990 & 1991 \\
\hline Not burned & $\begin{array}{l}0 \\
1 \\
2 \\
3\end{array}$ & $\begin{array}{l}-. \\
4,620 \\
4,210 \\
4,040 \\
2,760\end{array}$ & $\begin{array}{l}9,690 \\
4,870 \\
3,640 \\
2,530\end{array}$ \\
\hline March & $\begin{array}{l}0 \\
1 \\
2 \\
3\end{array}$ & $\begin{array}{l}4,380 \\
3,420 \\
3,440 \\
2,410\end{array}$ & $\begin{array}{l}5,840 \\
2,980 \\
2,700 \\
1,650\end{array}$ \\
\hline April & $\begin{array}{l}0 \\
1 \\
2 \\
3\end{array}$ & $\begin{array}{l}4,090 \\
3,090 \\
2,410 \\
2,410\end{array}$ & $\begin{array}{l}5,620 \\
3,110 \\
2,410 \\
1,860\end{array}$ \\
\hline May & $\begin{array}{l}0 \\
1 \\
2 \\
3\end{array}$ & $\begin{array}{l}2,850 \\
2,130 \\
1,860 \\
1,820\end{array}$ & $\begin{array}{l}3,710 \\
2,360 \\
1,900 \\
1,550\end{array}$ \\
\hline $\begin{array}{l}\text { Includes yielc } \\
2 \text { Harvest freq } \\
0=\text { No harve } \\
1=\text { June har } \\
2=\text { June and } \\
3=\text { June, Jul }\end{array}$ & $\begin{array}{l}\mathrm{d} \text { from growing-season } \\
\text { uency: } \\
\text { est during the growing-s } \\
\text { vest } \\
\text { July harvests } \\
\text { y, and August harvests }\end{array}$ & & \\
\hline
\end{tabular}

less new growth than burning in May. By the June harvest, not burned plots produced $53 \%$ of their total annual yield, plots burned in March 44\%, plots burned in April 43\%, and plots burned in May $18 \%$. In contrast, Ehrenreich and Aikmann (1957), working in lowa tallgrass prairies, found burned plots produced 43 to $47 \%$ of their total biomass by May 30 , while nonburned plots had produced only $19 \%$. In their study, heavy litter accumulation on non-burned areas kept soil temperatures low, and early burn dates (winter and early spring) allowed soils to warm and plants to grow earlier in the year.

Although yields were reduced by burning later in the spring in this study, canopy regeneration was quicker with later burn dates. Later burn dates minimized the length of time the soil surface was left without cover. Two weeks following the March, April, and May burns, light interception in these plots was 1, 5, and $22 \%$, respectively (Cuomo 1992). Rate of canopy regeneration may be important in areas with high erosion potential or low rainfall.

\section{Summer Growth}

By July the accumulated yield of plots harvested 2 and 3 times each growing season was 19 and $40 \%$ less $(\mathrm{P}=0.01)$, respectively, than plots harvested once per growing season. Unburned plots of all species yielded more $(1,730 \mathrm{~kg} \mathrm{ha})$ than plots burned in March $\left(1,220 \mathrm{~kg} \mathrm{ha}^{-1}\right)$, April $\left(1,120 \mathrm{~kg} \mathrm{ha}^{-1}\right)$, or May $\left(890 \mathrm{~kg} \mathrm{ha}^{-1}\right.$; P<0.01; L.S.D. at $\left.0.05=336 \mathrm{~kg} \mathrm{ha}^{-1}\right)$.

Species by harvest frequency interactions at the July harvest $(P=0.01)$ resulted from indiangrass producing less regrowth between the June and July harvests than the other species. At the August harvest, indiangrass also did not yield as much as the other species $\left(650,610\right.$, and $440 \mathrm{~kg} \mathrm{ha}^{-1}$ for switchgrass, big bluestem and indiangrass, respectively; $P=0.03$; L.S.D. at 0.05 $=120 \mathrm{~kg} \mathrm{ha}^{-1}$ ), but yields were low for all species. Low yields between the July and August harvest, and between the June and 
July harvest for indiangrass, indicate that removing all herbage to $18 \mathrm{~cm}$ in summer is a severe treatment.

\section{Soil Water Content}

Species by burn by harvest frequency interactions were not detected for soil water content in this study, but species by burn interactions were significant through most of the growing season (Table 5). Soil water content was lower in big bluestem and switchgrass monocultures, when burned in March compared with the other burn dates. In indiangrass monocultures, soil water content in March and April burned plots was generally less than unburned and May burned plots. Visual observation indicated that regrowth after burning was slower for indiangrass than for the other species, which may account for lower soil water content in indiangrass following April burning.

Reduced soil water content in March burned plots for all species, and March and April burned indiangrass plots may have been the result of the relatively long time the soil surface was

Table 5. Seasonal volumetric soil water content in plots seeded to switchgrass, big bluestem, and indiangrass at 4 burn dates. Values are averages across harvest treatments and years.

\begin{tabular}{|c|c|c|c|c|c|c|}
\hline \multirow[b]{2}{*}{ Species } & \multirow[b]{2}{*}{ Bum } & \multicolumn{5}{|c|}{ Season' } \\
\hline & & $\begin{array}{l}\text { Early } \\
\text { spring }\end{array}$ & $\begin{array}{l}\text { Late } \\
\text { spring }\end{array}$ & Summer & $\begin{array}{l}\text { Late } \\
\text { summer }\end{array}$ & fall \\
\hline Switchgrass & $\begin{array}{l}\text { Not burned } \\
\text { March } \\
\text { April } \\
\text { May }\end{array}$ & $\begin{array}{l}\ldots 2 \\
40 \\
42 \\
44\end{array}$ & $\begin{array}{l}44 \\
42 \\
43 \\
45\end{array}$ & $\begin{array}{c}\text { (5) } \\
43 \\
40 \\
43 \\
44\end{array}$ & $\begin{array}{l}37 \\
34 \\
37 \\
39\end{array}$ & $\begin{array}{l}38 \\
34 \\
38 \\
40\end{array}$ \\
\hline Big bluestem & $\begin{array}{l}\text { Not bumed } \\
\text { March } \\
\text { April } \\
\text { May }\end{array}$ & $\begin{array}{l}42 \\
38 \\
40 \\
41\end{array}$ & $\begin{array}{l}44 \\
40 \\
43 \\
44\end{array}$ & $\begin{array}{l}44 \\
39 \\
42 \\
44\end{array}$ & $\begin{array}{l}37 \\
33 \\
36 \\
37\end{array}$ & $\begin{array}{l}38 \\
33 \\
36 \\
37\end{array}$ \\
\hline Indiangrass & $\begin{array}{c}\text { Not bumed } \\
\text { March } \\
\text { April } \\
\text { May }\end{array}$ & $\begin{array}{l}44 \\
37 \\
37 \\
42\end{array}$ & $\begin{array}{l}46 \\
39 \\
43 \\
44\end{array}$ & $\begin{array}{l}45 \\
38 \\
40 \\
44\end{array}$ & $\begin{array}{l}39 \\
32 \\
33 \\
38\end{array}$ & $\begin{array}{l}40 \\
33 \\
38 \\
38\end{array}$ \\
\hline $\begin{array}{l}\mathrm{P}<\mathrm{F} \\
\mathrm{LSD} 0.05\end{array}$ & & $\begin{array}{l}0.01 \\
2.1\end{array}$ & $\begin{array}{l}0.01 \\
2.1\end{array}$ & $\begin{array}{l}0.01 \\
2.2\end{array}$ & $\begin{array}{l}0.01 \\
2.6\end{array}$ & $\begin{array}{l}0.61 \\
\text { NS }\end{array}$ \\
\hline
\end{tabular}

Tarly spring = 1 Mar.-2 Apr.

Late spring $=3$ Apr.-31 May

Summer $=1 \mathrm{June}-31 \mathrm{July}$

Late summer $=1$ Aug. -15 Sept.

Fall $=16$ Sept -1 Nov.

blackened and left exposed before new growth protected the soil surface following burning and to increased transpiration from additional growth on March and April compared with May burned plots. This additional moisture loss on early burned plots may be particularly important during moisture stress periods that often occur during late summer.

Evaporation from the soil and through transpiration appeared to have the greater impact on soil water content than infiltration. Runoff, and therefore less infiltration on burned plots, might be expected with the high intensity convectional storms that are common during spring. But, increases in soil water content from early-spring to late-spring were similar across all burn date treatments $(1.9,2.0,2.8$, and 2.2 percentage units for non-burned, March, April, and May burned plots, respectively). This implies that runoff and infiltration were similar among burned and not burned treatments during spring. This is in contrast to Anderson
(1965) and Anderson et al. (1970) who attributed part of the reduction in soil water content with burning to increased runoff.

Burn by harvest frequency interactions were also significant $(\mathrm{P}<0.05)$ for soil water content (Table 6). Where significant differences were detected (through summer in March burned plots, in early-spring in not burned plots, and in summer in April burned plots), non-harvested plots had less soil water than plots harvested 2 times $(\mathrm{P}<0.05)$. This was probably from more transpiration as a result of greater productivity on non-harvested plots (Tables 3 and 4).

No interactions were detected for soil water content during the late-summer and fall periods (Table 6), but March bumed plots had lower $(\mathrm{P}=0.01)$ soil water content than the other burn treatments in fall. Plots not harvested had lower soil water content $(\mathrm{P}=0.01)$ during the fall period than plots harvested 2 times each growing-season. Differences among species for fall soil water content were not significant $(\mathrm{P}=0.68)$.

Table 6. Seasonal volumetric soil water content for 4 burn treatments and 2 harvest frequencies in plots seeded to switchgrass, big bluestem, and indiangrass, values represent averages across species and years.

\begin{tabular}{lcccccc}
\hline \hline & & \multicolumn{5}{c}{ Season } \\
\cline { 3 - 8 } Burn & $\begin{array}{c}\text { Harvest } \\
\text { frequency }\end{array}$ & $\begin{array}{c}\text { Early } \\
\text { spring }\end{array}$ & $\begin{array}{c}\text { Late } \\
\text { spring }\end{array}$ & Summer & $\begin{array}{c}\text { Late } \\
\text { summer }\end{array}$ & Fall \\
\hline \multirow{3}{*}{ Not bumed } & 0 & -52 & 44 & 44 & 37 & 38 \\
& 2 & 44 & 44 & 39 & 40 & 40 \\
March & 0 & 37 & 39 & 38 & 35 & 32 \\
& 2 & 40 & 41 & 41 & 34 & 35 \\
April & 0 & 39 & 42 & 41 & 34 & 35 \\
& 2 & 41 & 43 & 42 & 37 & 40 \\
May & 0 & 43 & 45 & 44 & 38 & 38 \\
& 2 & 42 & 45 & 44 & 38 & 39 \\
P<F & & 0.01 & 0.01 & 0.01 & 0.22 & 0.28 \\
L.S.D. at 0.05 & & 2.0 & 1.8 & 1.3 & NS & NS \\
\hline
\end{tabular}

Early spring = 1 Mar.-2 Apr.

Late spring = 3 Apr.-31 May

Summer $=1$ June-31 July

Late summer = 1 Aug.-15 Sept.

Fall $=16$ Sept -1 Nov.

2 Harvest frequency:

$0=$ No harvest during the growing-season

$2=$ June and July harvests

\section{Management Implications}

Switchgrass, big bluestem, and indiangrass are all major components in fire-derived and maintained ecosystems. But, burning in consecutive years in this study was detrimental to the productivity of these species grown in monocultures. Burning reduced indiangrass yields the most and big bluestem yields the least. Because annual burning reduced productivity, burning in monocultures of these species should be used only to meet specific management objectives such as litter reduction and manipulating species composition.

Indiangrass tended to have less regrowth after harvest than the other species.Big bluestem yield decreased as the study progressed and was not benefitted by any treatment combination, but yield of not burned big bluestem declined more than yield of burned big bluestem. In this study, switchgrass was most tolerant of burning and harvest frequency treatments and may be the most 
desirable species for monocultures in this environment in terms of forage production.

Even though these grasses are an excellent forage resource, yields were reduced as harvest frequency increased for all species. Herbage production during any 30 day regrowth period between harvests never exceeded $880 \mathrm{~kg} \mathrm{ha}^{-1}$ in this study. Harvesting the entire canopy to a stubble height of $18 \mathrm{~cm}$ every 30 days did not meaningfully increase total annual yield, but reduced yield in subsequent years.

\section{Literature Cited}

Anderson, B. and A.G. Matches. 1983. Forage yield, quality, and persistence of switchgrass and Caucasian bluestem. Agron. J. 75:119-124.

Anderson, K.L. 1965. Time of burning as it affects soil moisture in an ordinary upland bluestem prairie in the Flint Hills. J. Range Manage. 18:311-316.

Anderson, K.L., E.F. Smith, and C.E. Owensby. 1970. Burning bluestem range. J. Range Manage. 23:81-92.

Cuomo, G. J. 1992. Burning and defoliation effects on the vigor and productivity of three warm-season grasses. Ph.D. Diss. Univ. of Nebraska, Lincoln, Neb.

Ehrenreich, J.H. and J.M. Aikmann. 1957. Effect of burning on seedstalk production of native prairie grasses. Proc. Iowa Acad. Sci. 64:205-212.

Greenhouse, S.W., and S. Geisser. 1959. On methods in the analysis of profile data. Psychometrika 32:95-112.

Hulbert, L.C. 1984. Fire effects on tallgrass prairie, p. 138-142. In: G.K. Clamby and R.H. Pemble (eds.), Proc. the North Amer. Prairie Conf., Morehead Minn.
Huynh, H. and L.S. Feldt. 1970. Conditions under which mean square ratios in repeated measurement designs have exact F-distributions. J. Amer. Stat. Assoc. 65:1582-1596.

Knapp, A.K. 1985. Effect of fire and drought on the ecophysiology of Andropogon gerardii and Panicum virgatum in a tallgrass prairie. Ecol. 66:1309-1320.

Maxwell, S.E. and H.D. Delaney. 1990. Designing experiments and analyzing data: A model comparison perspective. Wadsworth Publ. Co. Belmont, Cal.

McMurphy, W.E. and K.L. Anderson. 1963. Burning bluestem-forage yields. Kansas Acad. Sci. Trans. 66:49-51.

Mitchell, R.A. 1992. Effect of time, buming, fertilization, and atrazine on big bluestem yield and quality. M.S. Thesis, Univ. Nebraska. Lincoln, Neb.

Moser, L.E. and K.P. Vogel. 1995. Switchgrass, big bluestem, and indiangrass. p. 409-420. In: R. Barnes, D. Miller, and C.J. Nelson (ed), Forages. Iowa State Univ. Press.

Ogden, P.R. and W.F. Loomis. 1972. Carbohydrate reserves of intermediate wheatgrass after clipping and etiolation treatments. J. Range Manage. 25:29-32.

Owensby, C.E. and K.L. Anderson. 1967. Yield responses to time of burning in the Kansas flint hills. J. Range Manage. 20:12-16.

Rice, E.L. and R.L. Parenti. 1978. Causes of decreases in productivity in undisturbed tallgrass prairie. Amer. J. Bot. 65:1091-1097.

SAS Institute, Inc. 1988. SAS user's guide: Statistics. SAS Institute Inc., Cary N.C.

Svejcar, T.J. and J.A. Browning. 1988. Growth and gas exchange by Andropogon gerardii as influenced by burning. J. Range Manage. 41:239-244.

Weaver, J.E. and V.H. Hougen. 1939. Effect of frequent clipping on plant production in prairie and pasture. Amer. Midl. Natur. 21:396-414. 